18. Победнов Ю. А., Сычев А. М. Силосование провяленной люцерны в рулонах, упакованных в пленку, - альтернатива искусственной сушке // Животноводство и кормопроизводство. - 2018. - Т. 101, № 2. - С. 186-193.

19. Сычев А. М. Силосование провяленной люцерны в рулонах, упакованных в пленку, - альтернатива искусственной сушке // Научное и творческое наследие академика ВАСХНИЛ Ивана Семеновича Попова в науке о кормлении животных : материалы Междунар. науч.-практ. конф., посвящ. 130-летию со дня рождения выдающегося ученого в области кормления животных, педагога и общественного деятеля, профессора, академика ВАСХНИЛ, лауреата Ленинской премии И. С. Попова. - М., 2018. - С. 115-123.

20. Победнов Ю. А. Биоисточники масляной кислоты при провяливании люцерны // Проблемы биологии продуктивных животных. - 2020. - № 1. - С. 79-90.

21. Биологические источники сахара, аммиака и масляной кислоты при провяливании, сенажировании и силосовании люцерны / Ю. А. Победнов [и др.] // Проблемы биологии продуктивных животных. - 2018. - № 1. - С. 79-90.

22. Победнов Ю. А., Мамаев А. А., Широкоряд М. С. Биологические особенности силосования люцерны с препаратами молочнокислых бактерий // Кормопроизводство. - 2020. - № 3. - С. 43-46.

23. Победнов Ю. А. Исторический обзор развития силосования // Многофункциональное адаптивное кормопроизводство : сб-к науч. тр. - М., 2021. - 25(73). C. 119-143.

\title{
POBEDNOV'S PHENOMENON: SCIENTIFIC SEARCH AND ABERRATIONS
}

\section{V. Popov}

In polemic article short analysis of the concept of famous scientist Jury Andreevich Pobednov (30.01.1954 - 28.06.2021) on problem questions of forage ensiling technology is given.

Keywords: silage, haylage, leguminous and grasses, alfalfa, lactic acid bacteria preparations, butyric acid.

УДК 633:001.32

\section{СВЕТЛОЙ ПАМЯТИ УЧЕНОГО-ПОЛЕВОДА ХАРЬКОВА ГЕОРГИЯ ДМИТРИЕВИЧА (к 90-летию со дня рождения)}

\author{
Л. А. Трузина, кандидат сельскохозяйственных наук \\ ФНЦ «ВИК им. В. Р. Вильямса», г. Лобня, Московская область, Россия \\ na2012@yandex.ru
}

DOI: https://doi.org/10.33814/MAK-2021-26-74-151-155

Статья посвящена доброй памяти ученого-полевода Г. Д. Харькова, более полувека проработавшего в отделе полевого кормопроизводства ВНИИ кормов им. В. Р. Вильямса, начиная с аспиранта, затем младшим, старшим научным сотрудником, заведующим лабораторией, заведующим отделом. Г. Д. Харьков подготовил 18 канди- 
датов сельскохозяйственных наук, опубликовал более 200 научных работ. Защитил докторскую диссертацию. Высокая работоспособность и трудолюбие, глубокое познание научных истин, отзывчивость, внимательность, порядочность, жизнелюбие - все это о Георгии Дмитриевиче останется в нашей памяти.

Ключевые слова: Харьков Георгий Дмитриевич, 90-летие со дня рождения.

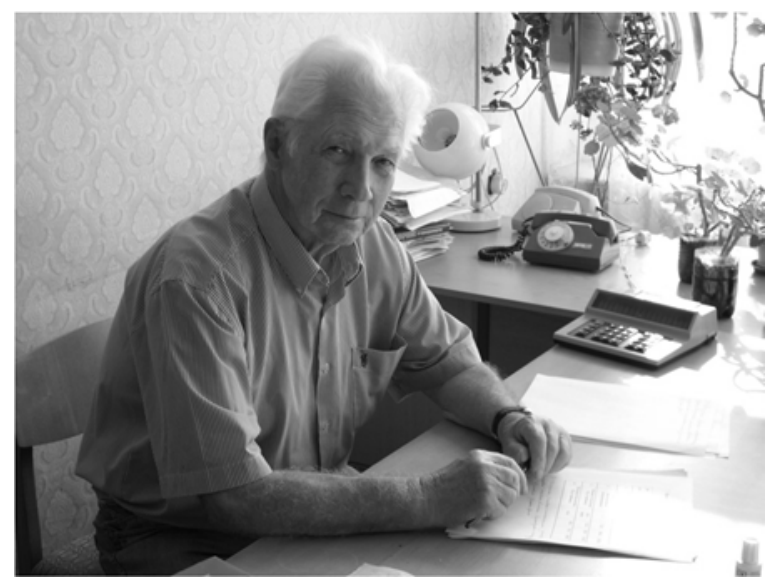

В 2021 г. ученому-полеводу Георгию Дмитриевичу Харькову исполнилось бы 90 лет.

Родился Георгий Дмитриевич 24 августа 1931 года в г. Ташкенте Узбекской ССР, в 1938 г. он вместе с семьей переехал в г. Петрозаводск, где родители работали в агрохимической лаборатории Карельской сельскохозяйственной опытной станции. В годы Великой Отечественной войны, с 1943 г., находился в эвакуации в Вологодской области, подростком совмещал учебу в школе с работой в колхозе. В 1946 г. семья вернулась в Карелию, и 8-10-й классы ему пришлось заканчивать в Сортавальской средней школе, которая находилась в 60 км от дома. После окончания школы в 1949 г. Георгий Дмитриевич поступил в Ленинградский сельскохозяйственный институт. После получения диплома ученого агронома в 1954 г. был направлен на работу в Псковскую область. Сначала работал агрономом и заместителем председателя, а затем председателем правления колхоза «Правда» Печорского района.

В 1959 г. решил попробовать свои силы и способности на научном поприще, сдал экзамены и поступил в аспирантуру при ВНИИ кормов имени В. Р. Вильямса. Успешно закончил ее в 1961 г. и был принят на должность младшего научного сотрудника отдела бобовых культур. В 1967 г. защитил кандидатскую диссертацию по клеверу луговому, как ценной кормовой культуре.

За период более чем полувековой трудовой деятельности работал и агрономом, и председателем колхоза, младшим, старшим научным сотрудником, заведующим сектором организации НИР, исполняющим обязанности заместителя директора ВИК по научной работе, заведующим лабораторией многолетних и однолетних бобовых культур, заведующим отделом полевого кормопроизводства.

Вместе с сотрудниками ВНИИ кормов, аспирантами и соискателями в течение 46 лет проводил полевые, вегетационные и лабораторные опыты, главным образом с такими многолетними бобовыми травами как клевер луговой, люцерна, эспарцет, донник белый, козлятник во- 
сточный. Кроме того, провел серию полевых опытов с многолетними злаковыми травами (ежой сборной, тимофеевкой луговой, кострецом безостым, овсяницей луговой, фестулолиумом), выращиваемыми в одновидовых и смешанных посевах с многолетними бобовыми культурами. Значительное место в исследованиях отводилось использованию в качестве покровных культур многолетних трав, ячменя, овса, яровой пшеницы на зерно, вико-овсяной смеси, кукурузы, проса, суданской травы, убираемых на зеленый корм и ранний силос. Много внимания в исследованиях уделялось разработке и совершенствованию технологий возделывания на зернофураж таких зернобобовых культур, как кормовые бобы, посевной горох, вика яровая и соя. С целью обогащения силоса растительным белком в условиях Северного Кавказа проводились исследования по подбору и оценке продуктивности смешанных посевов разнопоспевающих сортов зернового сорго с сортами сои и гиацинтовыми бобами.

Большое внимание Георгий Дмитриевич уделял методическим вопросам и подготовке научных кадров. Под его руководством успешно защитили кандидатские диссертации 18 аспирантов. Помимо Центрального района Нечерноземной зоны РФ, исследования проводились в Белоруссии, на орошаемых землях Крыма, в Казахстане, в Татарии, на Северном Кавказе, на северо-западе и северо-востоке европейской территории России.

На основании проведенных исследований и обобщения экспериментального материала автором отдельно и в соавторстве с научными сотрудниками и аспирантами опубликовано около 200 научных трудов: книг, статей и рекомендаций по различным вопросам полевого кормопроизводства:

- научное обоснование технологий создания высокопродуктивных травостоев многолетних трав в условиях интенсификации полевого кормопроизводства;

- особенности удобрения многолетних трав;

- применение микроудобрений на бобовых культурах;

- изучение продуктивности одновидовых и смешанных посевов многолетних трав;

- создание зеленого и сырьевого конвейеров из многолетних трав;

- разработка и совершенствование технологий возделывания зернобобовых культур на зернофураж;

- пути решения проблемы производства кормов и растительного белка.

В 2000 году Г. Д. Харьковым защищена диссертация на соискание ученой степени доктора сельскохозяйственных наук «Повышение эффективности полевого травосеяния и его роли в решении проблемы производства кормов в лесной зоне европейской части России». В 
2001 г. ему было присвоено ученое звание профессора по специальности «Растениеводство».

Георгий Дмитриевич до последнего дня оставался в строю, продолжал работать научным консультантом, являлся членом ученого совета ВНИИ кормов имени В. Р. Вильямса и специализированного совета по присвоению ученых степеней доктора и кандидата сельскохозяйственных наук. Будучи членом секции «Полевое кормопроизводство» Россельхозакадемии, многие годы координировал в СССР и Российской Федерации исследования по вопросам полевого травосеяния, был одним из руководителей общесоюзной и общероссийской программ НИР по полевому кормопроизводству.

Самым главным в жизни Георгия Дмитриевича, по его словам, были учеба и работа, которым он отдал более 65 лет. Любил сходить в театр - послушать оперу, посмотреть балет. В период отпуска ездил в Крым или на Черноморское побережье Кавказа. В годы перестройки о посещении театров и поездках куда-либо в период отпуска оставалось только мечтать, так как цены на билеты «кусались». Поэтому, как он сам писал: «Все свободное время, в том числе отпуска, работаю в садуогороде, где занимаюсь выращиванием ягод, фруктов, овощей и картофеля, практически полностью снабжаю продукцией всю семью. Изредка читаю художественную литературу, смотрю телевизор, к юбилейным датам родственников и сослуживцев, к празднику 8 Марта и некоторым знаменательным датам пишу стихи. Как и все, не теряю надежду на лучшее будущее...».

Из стихотворения Г. Д. Харькова «Немного о себе»:

Я из поэтов Пушкина люблю.

Его стихи бальзамом на душу ложатся:

Они прекрасны, не содержат лжи

И не таят в себе лукавства.

Жить честно, злобы не тая

На сослуживцев, или на соседа -

Такая линия моя. Хотя она трудна

И не всегда находит должного ответа.

Мне в жизни, в общем, повезло:

Я больше знал людей надежных и приятных,

Кто честь свою не запятнал

И в трудную минуту руку мне подал.

Я уважаю труд,

Страну люблю родную,

Но горько от того,

Что плохо мы живем.

Куда же мы идем? Богатая страна,

Но резкие контрасты:

Кто в роскоши купается,

Кто в нищете живет... 
...Когда же к нам придут прозренье и отвага, Когда сплотится наш поруганный народ?

Когда с лица земли сметет всю нечисть без возврата И жизнь достойную себе приобретет?

Август 2006 г.

В науке его жизненное кредо осталось неизменным: высокая самоотдача труду, глубокое познание научных основ агротехники многолетних трав, бескорыстная передача полученных знаний своим аспирантам и товарищам по работе, активное участие в общественной жизни ВНИИ кормов, за что Георгий Дмитриевич снискал глубокое уважение к себе товарищей по работе и дирекции Института.

Из воспоминаний его товарищей:

В. А. БОНДАРЕВ: «Георгий Дмитриевич прошел нелегкий жизненный путь. Но прошел его с достоинством, являясь образцом для многих людей нашего общества по культуре в быту, отношению к работе, созданию семьи. В лице Георгия Дмитриевича Институт кормов потерял талантливого увлеченного работой ученого, а товарищи по работе - добросердечного, отзывчивого, внимательного, большой чести человека».

А. А. ЗОТОВ: «Несмотря на то, что он был полевод, мы находили общие темы для разговора, из которых было видно, что он неплохо разбирался и во многих вопросах лугового кормопроизводства. С ним было приятно работать, бывать в командировках, участвовать в различных общественных мероприятиях. Георгий Дмитриевич был хорошим семьянином. Все заботы по содержанию «фазенды» он брал на себя: сам копал землю, сеял, сажал различные культуры, удобрял почву самодельным компостом, применял на участке передовую агротехнику, новые сорта, ввел на огороде трехпольный севооборот. Он был человеком от земли, мастером на все руки: умел выращивать рассаду, заготавливать всякие соленья-варенья, изготавливать домашние вина».

Простой и скромный в обращении с людьми, рассудительный, добрый, порядочный, общительный, веселый и жизнерадостный, трудолюбивый — таким в нашей памяти остался Георгий Дмитриевич Харьков.

\section{BRIGHT MEMORY TO THE SCIENTIST-AGRICULTURIST KHARKOV GEORGY DMITRIEVICH (to the 90th anniversary of his birth)}

\section{A. Truzina}

The article is devoted to the good memory of the scientist-agriculturist Kharkov Georgy Dmitrievich, who worked for more than half a century in Williams Fodder Research Institute, starting with a graduate student, then as a junior, senior researcher, head of the laboratory and head of the department. He prepared 18 candidates of agricultural sciences, published more than 200 scientific papers. He defended his doctoral dissertation. High efficiency and diligence, deep knowledge of scientific truths, responsiveness, attentiveness, decency, zest for life - all this about Georgy Dmitrievich will remain in our memory.

Keywords: Kharkov Georgy Dmitrievich, 90th anniversary of his birth. 